\title{
Climate change adaptation in fisheries
}

\author{
Eranga K. Galappaththi ${ }^{1,2}$ (D) | Vasantha B. Susarla ${ }^{2}$ (D) | Samantha J. T. Loutet $^{2}$ (D) | \\ Stephanie T. Ichien ${ }^{3}$ (D) | Amanda A. Hyman ${ }^{4}$ (D) | James D. Ford ${ }^{5}$ (C)
}

${ }^{1}$ Department of Geography, Virginia Tech, Blacksburg, VA, USA

${ }^{2}$ Department of Geography, McGill University, Montreal, QC, Canada

${ }^{3}$ Oregon Sea Grant, Oregon State University, Corvallis, OR, USA

${ }^{4}$ Department of Ecology and Evolutionary Biology, University of Tennessee, Knoxville, TN, USA

${ }^{5}$ Priestley International Centre for Climate, University of Leeds, Leeds, UK

\section{Correspondence}

Eranga K. Galappaththi, Department of Geography, Virginia Tech, Blacksburg, VA, USA.

Email: eranga.research@gmail.com

Funding information

Social Science Research Council, Grant/

Award Number: 752-2016-0148

\begin{abstract}
We conducted a global systematic literature review of climate change adaptation in fisheries. We addressed three specific questions: (i) What are fisheries adapting to? (ii) How are fisheries adapting? and (iii) What research gaps need to be addressed? We identified, characterized and examined case studies published between 1990 and 2019 that lie at the intersection of the domains of climate change, adaptation and fisheries. We characterized the documented climate change effects in fisheries that are being adapted to multiple stressors, general climate impacts, extreme events, ocean conditions, marine system shifts, climate variability, fishery dynamics, species distribution and atmospheric warming. Three categories of adaptive responses came to light: coping mechanisms (e.g. changing fishing location, use of traditional knowledge); adaptive strategies (e.g. livelihood diversification, incorporation of technology); and management responses (e.g. adaptive management, adaptation planning). We identified key potential areas for future research, including studies on the limits and barriers for adaptation, studies using specific conceptual and methodological approaches, and studies focussing on the top-producing countries such as China, Indonesia, Peru and Russia. This analysis gives broader insights to the fisheries industry and to climate change adaptation research to proceed in the face of new global challenges.
\end{abstract}

\section{KEYWORDS}

adaptation limits, adaptation tracking, global assessment, management approaches, research directions, systematic literature review

\section{1 | INTRODUCTION}

Fisheries is one of the sectors most vulnerable to climate change because of its sensitivity to environmental conditions and substantial role in feeding people and supporting livelihoods. The industry is crucial for the nutrition and food security of the growing world population. Over $87 \%$ of global fish production is used for human consumption, which totals to 156 million tonnes and equates to $20.5 \mathrm{~kg}$ per capita (FAO, 2020; Loring et al., 2019). In 2018, the industry was worth over USD 401 billion, supporting $~ 60$ million people in capture fisheries alone (FAO, 2020). Climate change impacts, however, generate various adverse effects on aquatic systems, vulnerable fisher populations and associated industries relying on fisheries, along with creating potential opportunities in some regions. Many of these projected climate implications will be novel; therefore, implementing some degree of adaptation is essential for global food and livelihood security, poverty alleviation and sustainable fisheries (de Coninck et al. 2018).

Adaptation to climate change in fisheries requires a greater understanding of what adaptations are needed, occurring and viable, as well as those that need further support to manage the ongoing and future challenges of the industry. The impacts of climate 
change will continue to add to the complexity and uncertainty of fisheries systems (the social-ecological systems associated with fisheries operation), which can result in various unfavourable conditions (e.g. social, ecological and economic impacts) (Johnson et al., 2019). Climate change impacts under other multiple stressors (e.g. COVID, overfishing, pollution) will further augment the need for resilience of fisheries systems (Bennett et al., 2020; Bindoff et al., 2019). With an increase in research focussed on the human dimensions of climate change adaptation, limited research assesses and characterizes adaptations specific to the fisheries sector (with the exceptions of FAO reports) (Barange \& Cochrane, 2018; Daw et al. 2009; FAO, 2018, 2020; Seggel \& De Young, 2016). To the best of our knowledge, no global systematic assessment of the climate change adaptation literature in the fisheries sector is available (excluding aquaculture) (Galappaththi et al., 2020). We, however, also acknowledge the assessments on changing aquatic ecosystems (Bindoff et al., 2019), climate-ready fisheries (Bell et al., 2020) and adaptation strategies in marine systems (Miller et al., 2018). Against this backdrop, an examination of global fisheries systems is necessary to advance the understanding of how they experience shocks and stressors and how such systems respond and adapt to climate change impacts.

In this article, we identify and examine 230 case studies across the globe that were published between 1990 and 2019 and lie at the intersection of fisheries, climate change and adaptation. This allows us to develop understanding on the emergence and nature of research on climate change adaptation in the social-ecological systems associated with fisheries operations around the world. Climate change adaptation in a fisheries context is a growing research field that has received increasing attention, but no comprehensive assessment has been conducted. We sought to fill this gap by addressing three primary questions related to global fisheries: (i) What are fisheries systems adapting to? (ii) How are fisheries systems adapting? and (iii) What research gaps need to be addressed? There is a growing interest in tracking and systematically assessing adaptation with sectoral coverage (e.g. aquaculture) (Galappaththi et al., 2020), though none of these works focusses more broadly on fisheries. Thus, this study brings novel insights to the field of fisheries and climate change adaptation.

\section{2 | METHODS}

We used a systematic literature review approach to examine the literature of adaptation to climate change in the context of fisheries between 1990 and 2019. Unlike a traditional literature review, a systematic literature review uses an explicit and rigorous methodology involving transparent and objective criteria (Ford \& Pearce, 2010). The climate change adaptation literature has increasingly adopted this approach to synthesize prior results and identify knowledge gaps for future work (Ford \& Pearce, 2010; Petticrew \& McCartney, 2011). Following BerrangFord et al. (2015), we first identified the data source, with

\begin{tabular}{ll}
\hline 1. INTRODUCTION & 1 \\
\hline 2. METHODS & 2 \\
\hline 3. RESULTS & 3 \\
\hline 3.1 Descriptive results & 3 \\
\hline 3.2 Types of targeted fisheries & 4 \\
\hline 3.3 Theoretical approach towards studying climate & 5 \\
\hline adaptation in fisheries & \\
\hline 3.4 Climate change impacts & 6 \\
\hline 3.5 Coping responses in fisheries & 6 \\
\hline 3.6 Adaptive strategies in fisheries & 9 \\
\hline 3.7 Management responses in fisheries & 9 \\
\hline 3.8 Limits to adaptation in fisheries & 10 \\
\hline 3.9 Policy contributions & 10 \\
\hline 3.10 Grey literature assessment & 11 \\
\hline 4. DISCUSSION & 12 \\
\hline 5 OPPORTUNITIES AND DIRECTIONS FOR FUTURE & 13 \\
\hline RESEARCH & 14 \\
\hline ACKNOWLEDGEMENTS & 14 \\
\hline REFERENCES & \\
\hline
\end{tabular}

documentation of the search and selection process. The authors then developed the inclusion and exclusion criteria for literature in a collaborative approach. In the second phase, we defined the methods used for analysis and critical appraisal of the information quality of this study.

To meet the aim of the research, we evaluated literature at the intersection of climate change, adaptation and fisheries. Previous fisheries assessments on global climate change adaptation have focussed on both fisheries and aquaculture (Barange et al. 2018; FAO, 2019; Johnson et al., 2019). Yet, we excluded aquaculture from the broader fisheries scope, as climate change adaptation in aquaculture has recently been examined (Galappaththi et al., 2020). We included peer-reviewed publications from academic journals and book chapters from any discipline that met the search criteria. Using the search engine Web of Science (WOS), one search was conducted. The search terms were "climat* chang*", "fish*", and "adapt" in the TOPIC category in the time frame 1990-2019 (Table S1). The search was conducted in January 2020 and captured all publications in the specified timeframe. The search terms returned peer-reviewed publications that included ALL of the word fragments in the search string as part of the publications' TOPIC, and the Digital Object Identifier was used to eliminate duplicates.

The initial data set included 2,401 publications and was exported to Microsoft Excel. In the first screening of the data set, the authors read the titles and abstracts of the publications (and the full text in cases in which the classification was doubtful) to determine which publications would be included in the final data set (Table 1: inclusion criteria). For example, studies that used vulnerability as the primary analysis approach were excluded because adaptation and vulnerability are similar but distinctly separate approaches to climate change research. 
TAB LE 1 Inclusion and exclusion criteria for document selection

\begin{tabular}{|c|c|c|c|}
\hline Particulars & Inclusion & Exclusion & $\begin{array}{l}\text { No. of studies } \\
\text { excluded }\end{array}$ \\
\hline Language & English & Non-English & 1 \\
\hline Publication type & Research articles, case studies & $\begin{array}{l}\text { Synthesis, abstracts, editorials, reviews, meetings/workshops, } \\
\text { insights, frameworks }\end{array}$ & 119 \\
\hline Who adapts? & People/social adaptation & $\begin{array}{l}\text { Natural systems, fish, plants (e.g. studies on how fish adapt to } \\
\text { temperature variations) }\end{array}$ & 308 \\
\hline $\begin{array}{l}\text { Responses, activities } \\
\text { and actions }\end{array}$ & Adaptation responses & $\begin{array}{l}\text { Mitigation, vulnerability (e.g. studies using vulnerability } \\
\text { frameworks as the principal theoretical approach) }\end{array}$ & 80 \\
\hline Focus & Practical & $\begin{array}{l}\text { Conceptual, theoretical, models (e.g. conceptual frameworks and } \\
\text { adaptation modelling) }\end{array}$ & 47 \\
\hline Time & Present & $\begin{array}{l}\text { Prehistoric, future (e.g. studies aimed at the prehistoric } \\
\text { adaptation of fisheries and fish populations) }\end{array}$ & 10 \\
\hline Industry & $\begin{array}{l}\text { Fisheries and/or integrated } \\
\text { systems }\end{array}$ & $\begin{array}{l}\text { Others including aquaculture (e.g. rice-fish culture, agriculture, } \\
\text { forestry) and fish ecology }\end{array}$ & 388 \\
\hline Change & Climate-change-related & $\begin{array}{l}\text { Not related to climate change (e.g. globalization, impacts of } \\
\text { economic recession) }\end{array}$ & 27 \\
\hline
\end{tabular}

The authors then characterized the 1,211 publications that were retained in the data set for a more detailed screening. Throughout the screening and data collection process, the authors met virtually on a weekly schedule to ensure consistency in characterization. Careful documentation of reasons for eliminating a publication at this stage was captured on the Excel sheet. The final set of publications explicitly addressed the impacts of climate change and the various adaptation strategies used in fisheries. By contrast, all excluded publications did not address topics at the intersection of adaptation, climate change and fisheries or focussed on only one or two of those domains. Based on this secondary analysis, 230 articles were retained for final review. In addition to the citation data, the authors collected specific data on each retained publication, that is first-author affiliation, key funding sources, research location, target population of study, type of fisheries and policy implications (Table S2). Finally, before data analysis, the lead author conducted a comprehensive review of the final data set for consistency in characterization.

Two hundred and thirty articles focussed on individual and multiple case studies, though the term "paper" is used as a unit of analysis. The term "case studies," used in the remainder of the text, refers to the number of papers reviewed rather than the specific case studies of focus within any given paper. A qualitative content analysis was used for the final analysis, which is often used to analyse selected text (Krippendorff, 2018; Vaismoradi et al., 2016). "Manifest" and "latent" content analysis (Krippendorff, 2018) were used as the primary techniques, supplemented by with "discourse" analysis (Fairclough, 2013) to reveal themes and linkages within the data set. Direct quotations from the papers were also used to capture the original content. Most of the descriptive statistics reported were formulated in Microsoft Excel 2013, with percentages referring to the total sample size $(n=230)$. Percentages in the text refer to the number of respondents from the immediately mentioned sub-sample.
We also conducted a separate mini-assessment of grey literature to understand how differently (or similarly) peer-reviewed literature documents climate change adaptation in fisheries. The inclusion of grey literature is essential to the study because much of the evidence on climate change adaptation is documented there. We conducted a grey literature search using multiple search engines such as university library resources, Google Scholar and various public-facing databases (e.g. FAO; Piggott-McKellar et al., 2019). We used purposive sampling (Etikan et al., 2016) for the grey literature search due to the scattered nature of the non-peer-reviewed literature. However, we used the same exclusion criteria (Table 1) with adjustments for the publication types by including grey literature such as reports and conference proceedings. We screened 111 documents and yielded 43 items for final coding. Coding questions were designed to capture highlighted topics that emerged from the peer-reviewed assessment and to collect additional data under the "other" category to capture data specific to grey literature. The coded data were analysed using the same techniques used for the peer-reviewed assessment.

\section{3 | RESULTS}

\section{1 | Descriptive results}

Our study collects insights from 230 publications studying the intersection of climate change, fisheries and adaptation. From 2006, the total number of articles at this intersection increased until 2018, after which it dropped off slightly (Figure 1). North America and Oceania lead in number of publications, while South America shows relatively slow progress. At the country level, the USA (23\%), Australia (19\%) and Canada (11\%) have the highest number of publications. Based on the first-author's affiliation, the top four institutions that produced publications are as follows: The 

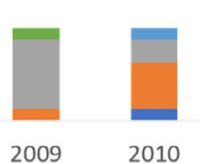

2011

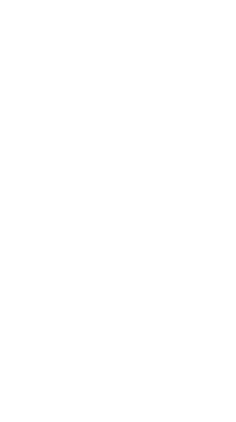

africa north America

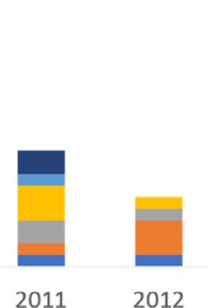

2012

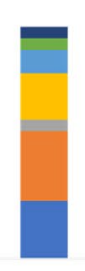

2014

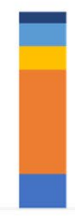

2015

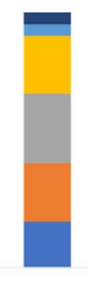

2016

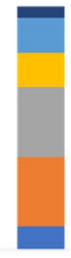

2017

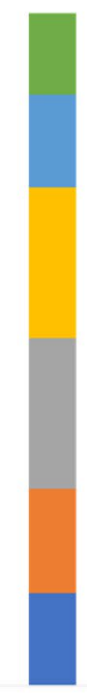

2018

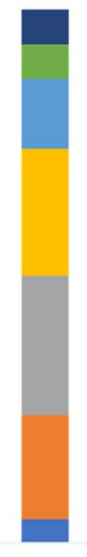

2019

FIGURE 1 Publications at the intersection of climate change, adaptation and fisheries per journal per year from 2006 to 2019 . The figure illustrates the development of continent-level publications (based on the first-author affiliation)

Commonwealth Scientific and Industrial Research Organisation (CSIRO), Australia $(n=11)$; Stanford University, USA $(n=6)$; and James Cook University $(n=4)$ and the University of Tasmania $(n=4)$, Australia. Most of the case studies are published in leading peer-reviewed disciplinary journals such as Marine Policy (11\%), Ocean and Coastal Management (7\%), Ecology and Society (6\%) and ICES Journal of Marine Science (4\%). The top five research destination countries recoded are the USA (16\%), Australia (11\%), India (5\%), Bangladesh (5\%) and Canada (4\%).

The majority (62\%) of case studies used a mixed approach with both qualitative and quantitative research designs, while the rest of the studies used either qualitative (26\%) or quantitative (12\%) approaches. The majority (57\%) of studies were based on primary data; and $27 \%$ of them were based on secondary data, while $17 \%$ were mixed. The use of primary data for research became increasingly popular from 2006 to 2019. In terms of funding sources, governments funded the majority $(66 \%)$ of the literature, with the three most common funders being the National Science Foundation (6.0\%), Social Sciences and Humanities Research Council of Canada (4.3\%) and Fisheries Research and Development Corporation of Australia (3.8\%).

\section{2 | Types of targeted fisheries}

Studies focussed on various fisheries systems across 56 countries. We analysed the continent-level distribution of targeted fisheries using three categories: marine (saltwater) fisheries; inland (freshwater) fisheries; and brackish (mixed-water) fisheries (Figure 2). We found 178 marine fisheries and equal amounts $(n=33)$ of inland and brackish water systems across six continents. Marine fisheries are the most studied fisheries among all the continents. Oceania and Africa consist of the highest (96\%) and lowest (47\%) proportions of studied marine fisheries. Inland fisheries are the least studied fisheries on many continents, with exceptions being Africa (39\%). Oceania shows the lowest proportion of inland (2\%) studies and brackish water (2\%) fisheries.

Species-specific studies indicate a large range of species diversity. For example, North America has the highest portion (37\%) of species-specific studies, including Eastern Oyster (Crassostrea virginica, Ostreidae), Groupers (Epinephelus malabaricus, Serranidae), Parrotfish (Scarus frenatus, Scaridae), Spiny lobster (Panulirus argus, Palinuridae), Atlantic cod (Gadus morhua, Gadidae), Greenland Halibut (Reinhardtius hippoglossoides, Pleuronectidae) and Atlantic Salmon (Salmo salar, Salmonidae). The most studied marine species groups are Lobster (family: Nephropidae), Mackerel (family: Scombridae), Herring (family: Clupeidae), Tuna (family: Scombridae) and Cod (family: Gadidae). The most studied inland fisheries species groups are Tilapia (family: Cichlid) and Catfish (family: Ictalurids). The most studied brackish water species groups were Oyster (family: Ostreidae) and Crabs (order: Decapoda).

In terms of the scale of targeted fisheries, many (93\%) of the fisheries are at the community (30\%) and regional (63\%) levels. Only $4 \%$ of studies represent national- and international-level marine fisheries, and this varies from $0 \%$ to $3 \%$ for inland and brackish water fisheries. 


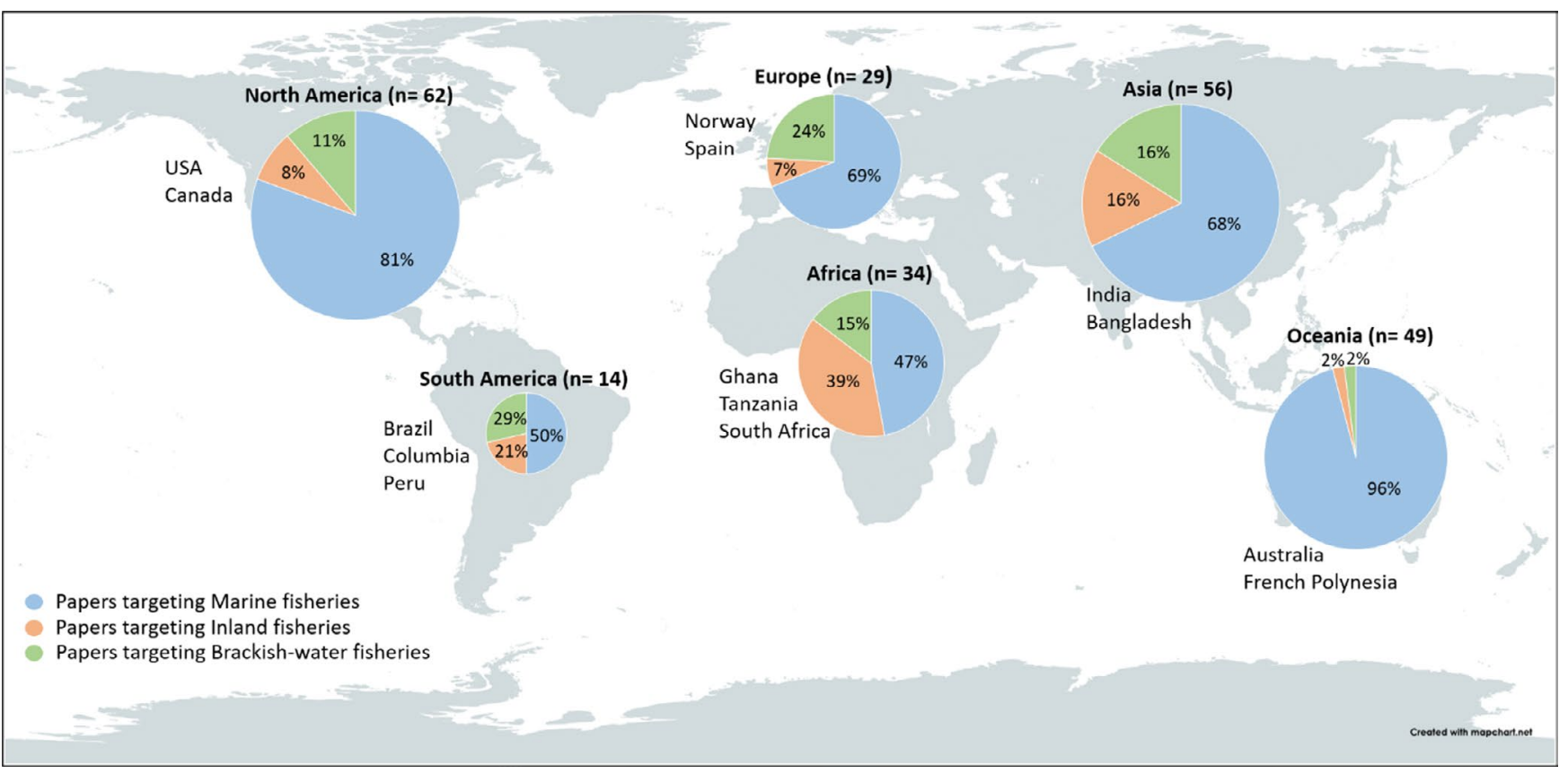

FIGURE 2 Types of fisheries studied (marine, freshwater and brackish) on different continents. We found only one article related to the Antarctic continent, but it is not included here. Further, the figure shows the top two research destination countries based on the number of fisheries studied related to each continent (South America and Africa list three countries because of its presents of equal data frequencies)

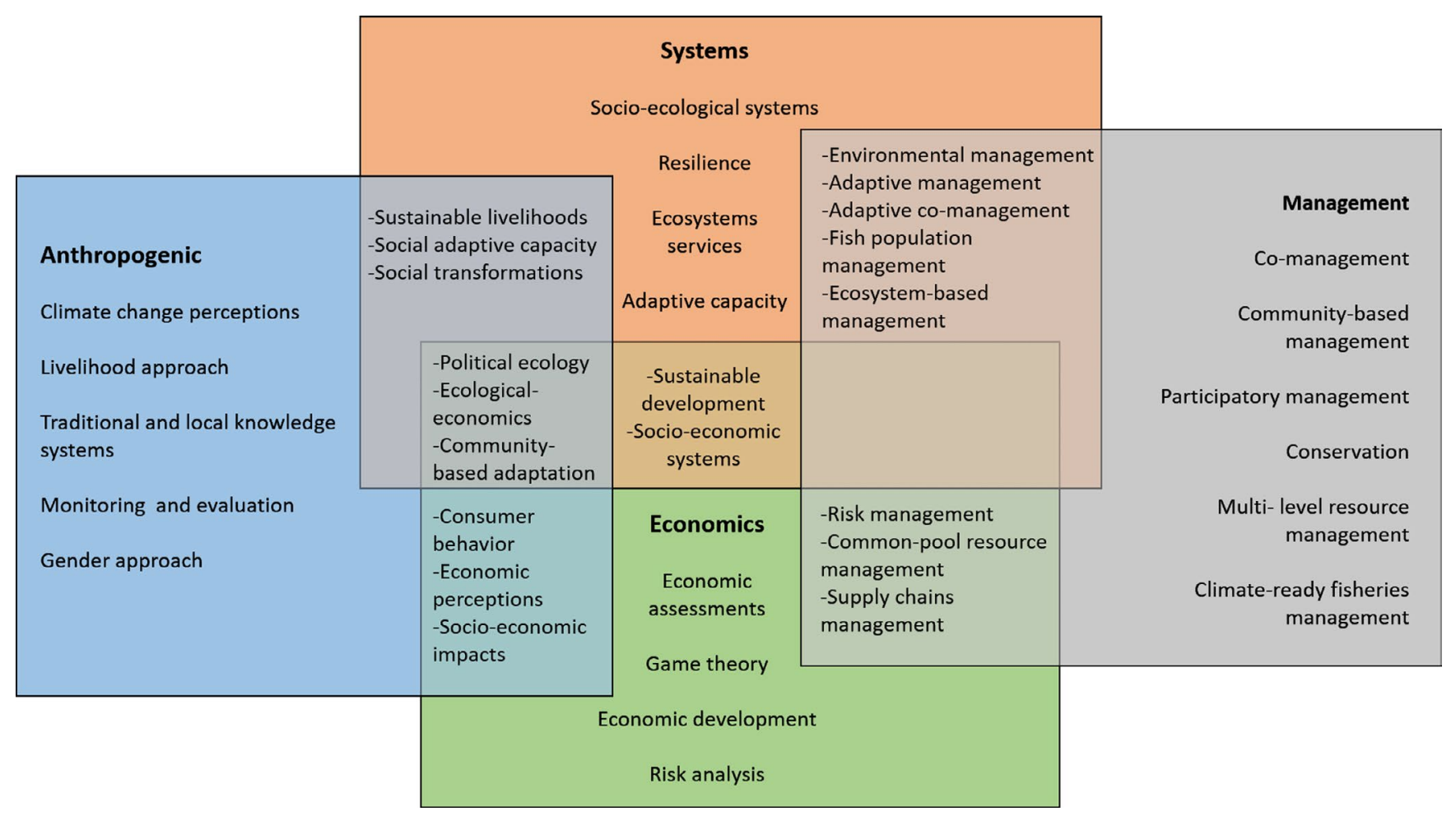

FIGURE 3 Thematic Venn diagram of the key conceptual areas used for climate adaptation in fisheries. Please refer to Table S3 for definitive criteria used to develop climate change impact categories

\subsection{Theoretical approach towards studying climate adaptation in fisheries}

The majority $(>50 \%)$ of studies adopted integrated approaches to study climate change adaptation in fisheries. For example, to examine the impact of tropical cyclone Winston on female mud crab (Scylla serrata, Portunidae) fishers in Fiji, researchers used multiple approaches of social-ecological systems, economic assessments, supply chain management and gender differences (Thomas et al., 2019). 
We identified four primary thematic areas based on the conceptual approach used to study climate adaptation: systems approach; management; economics; and anthropogenic (Figure 3). The guiding question used for the thematic area development is What is the relevance of the conceptual approach to the specific area of climate adaptation discussed in the study? First, the systems approach is consistent with four main theoretical bodies: social-ecological systems, resilience, ecosystem services and adaptive capacity. Many (34\%) of the studies used a systems approach; for example, Forbes (2013) used a socialecological systems lens to study the cultural resilience of hunting and fishing practices of the Nenets and Yamal-Nenets of Russia. Second, the thematic area of management (27\%) consists of co-management, community-based management, climate-ready fisheries management, participatory management, conservation and multi-level resource management. The overarching focus of these papers is to investigate how to better manage fisheries (in light of multiple stresses). For instance, Ensor et al. (2018) found that the application of communitybased adaptation improved the resilience of coastal fisheries in the Timor-Leste and Solomon Islands.

Third, the conceptual areas of game theory, economic development, risk analysis and economic assessments are characterized under the thematic area of economic (21\%). For example, Chaijaroen (2019) applied a framework of labour supply/consumption to assess long-lasting income shocks and food security-related adaptations in the context of coral bleaching in Indonesia. Fourth, in the thematic area of anthropogenic (18\%), we recorded conceptual approaches, including climate change perceptions, livelihoods, traditional and local knowledge systems, gender and monitoring (Codjoe et al., 2012; Vogt et al., 2016). Further, we identified distinct integrated conceptual approaches that overlap among the four primarily identified thematic areas (e.g. common-pool resource management, socio-economic systems, community-based adaptation, sustainable livelihoods and ecosystem-based management; Blanco et al., 2015).

\subsection{Climate change impacts}

The majority (63\%) of studies identified climate change as the key driver for changes in fisheries systems (Figure 4; Table S3). Over onethird $(36 \%)$ of case studies identified multiple stressors of climate change, which created complex problems for fisheries. For example, Frawley et al. (2019) found that changes in wind and weather patterns, physical changes to the marine environment and variation in animal behaviours were commonly reported as barriers to the livelihoods of small-scale fishers off the Gulf of California in Mexico. The broad implications of general climate change impacts were also studied (12\%); if no specific stressors were mentioned, climate change was analysed as a single macro-impact. Other papers examined individual stressors including extreme events (13\%; e.g. marine heatwaves), ocean conditions (13\%; e.g. ocean acidification), shifting marine systems ( $9 \%$; e.g. food web changes), climate variability (5\%; e.g. changes in weather patterns), fishery dynamics (4\%; e.g. changing fishing seasons), species distributions (4\%; e.g. changes in fish migration patterns) and atmospheric warming (3\%; e.g. changes in average temperature). Some studies revealed that pollution from boat traffic and human development, on top of climate change, had a combined influence on fisheries and their adaptive capacity (van Putten et al., 2013, 2016).

Tied to ocean conditions, extreme events accounted for the most recorded individual climate change impact. These are some of the most visible consequences of climate change for fishers in the field; there is no way to ignore the effects of El Niño Southern Oscillation, tropical storms, floods, droughts and other natural disasters, which can decrease catch and result in long-term fluctuations in fishing activities (Arias Schreiber et al., 2011; Thomas et al., 2019). As these natural disasters continue to threaten the feasibility of the fishing industry, inland fisheries are often studied alongside the agricultural sector to examine viable alternative livelihoods (Bahadur et al., 2019; Limuwa et al., 2018). For marine and coastal fisheries, changing ocean conditions such as acidification, rising sea levels, increasing sea surface temperatures and ice melt are driving factors for adaptation. These water conditions impact ecosystem prosperity across the globe. Marine system shifts such as coral bleaching, the introduction of invasive or outsider species, harmful algae blooms and lessening biodiversity can result in the closure of entire fishing areas and lasting changes to biophysical systems (Camargo et al., 2009; Collin et al., 2015).

Moreover, climate variability can cause unpredictability in ecosystem patterns upon which fishers may have previously relied, affecting their ability to plan for the future (Zhang et al., 2012). Changing ecosystems can also drive socio-economic factors such as tourism, poverty and reduced employment, which affect internal fishery dynamics (Klain et al., 2014). Established species cannot continue to thrive in their traditional regions when climates fluctuate, impacting oceans from tropical coral reefs to the Arctic by changing species distributions (Galappaththi et al., 2019). Many species have even migrated outside of fishable regions to escape an unwanted climate, thereby forcing fisheries to adapt (CisnerosMontemayor et al., 2016). Atmospheric warming can be a cause of these changing species distributions and presents its own host of additional complications. This type of warming alone, independent of rising sea surface temperatures, is examined in just $3 \%$ of cases and has an increased impact on inland fisheries, which lack the moderating effects of the ocean on atmospheric temperatures (Magee et al., 2019).

\subsection{Coping responses in fisheries}

Coping responses refer to short-term responses, including autonomous responses to climate change and associated impacts (Arias Schreiber et al., 2011). We found that documented coping measures are mostly in response to climate impact categories related to extreme events $(n=13)$ and marine systems ( $n=9$; Table S5). Coping measures are responses to complex and multiple impacts that represent direct and indirect climate change impacts (Table 2). 


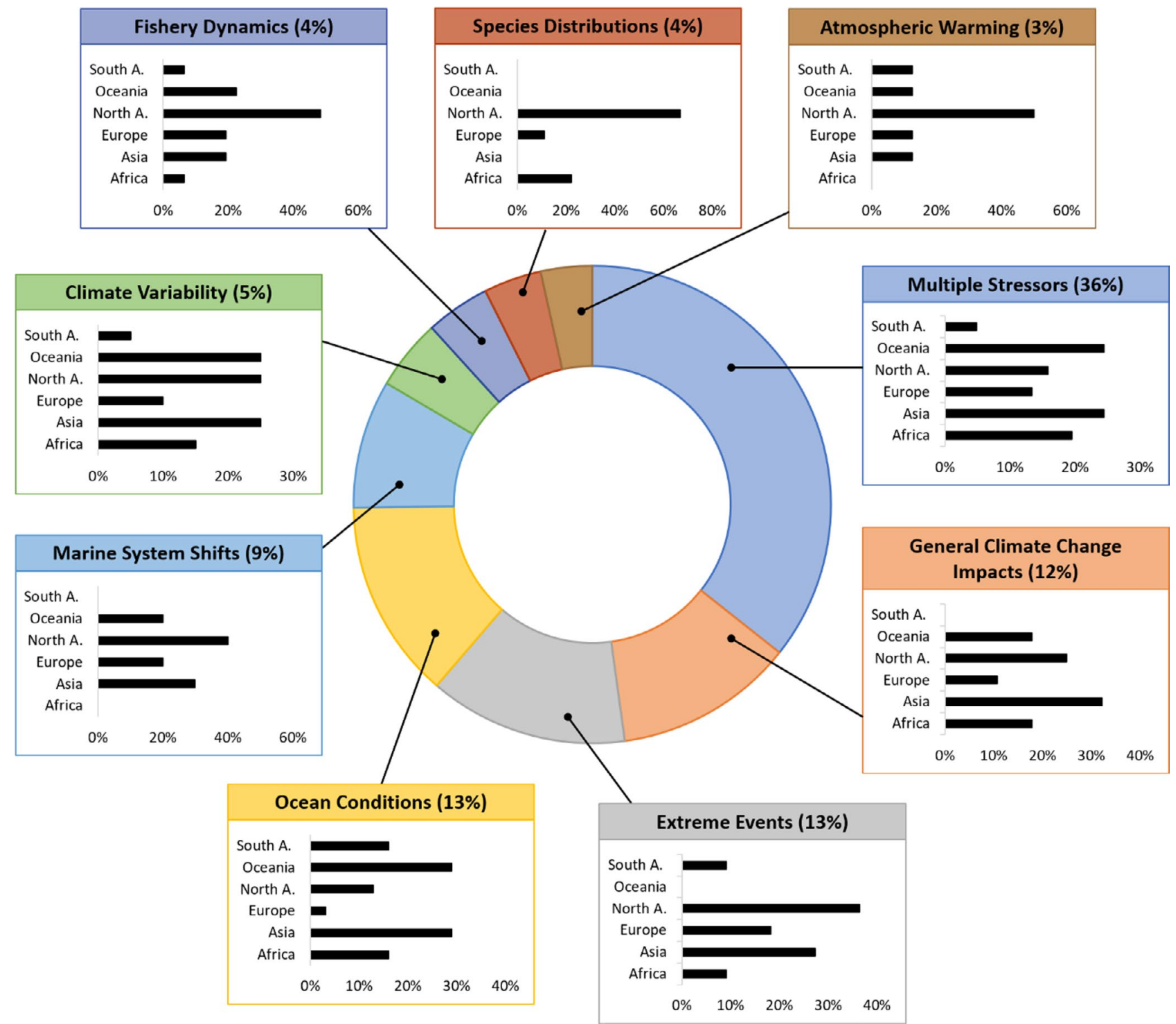

FIGURE 4 Climate change impact categories vs. research continent. The donut chart shows climate change impact categories as a fraction of total papers. Each climate change impact is further broken down in a bar chart which shows the fraction of papers in that category from each research continent. Please refer to Table S3 for definitive criteria used to develop climate change impact categories

For example, skippers in the areas of Newlyn, Cornwall, Southwest England, are responding to increasing fuel prices by adopting various reactions, including: use tidal current more often to save fuel; reduce steaming and towing speed; reduce the number of days at sea; take more risk with weather to increase fishing days at sea; and attempt to increase the quality of fish caught to improve income (Abernethy et al., 2010). We also found strategies to cope with the hardship of fisheries undergoing multiple stressors including fish species migration and fish market volatilities. For example, many Southern Cape line fishers in South Africa proceed to sea only when a profitable catch is guaranteed, which relied on feedback from other fishers as well as one's own knowledge of sea conditions and local weather (Gammage et al., 2017).
Responses across studies vary based on the type of fishery and geographical region, but we found specific behavioural responses commonly used at the local level. Changing fishing locations, targeting other species, using different gear, and decreasing/increasing fishing days and time on fishing grounds are standard practices among artisanal fisheries, mostly in the developing context. For example, based on the research into small-scale coastal and floodplain fishing communities in Bangladesh, Deb and Haque (2017) found that communities apply numerous coping strategies, including psychological preparation and planning for the worst case scenario; storage of dry foods and essential items for difficult times; and the repair of small boats or the making of rafts with banana plants or bamboo. Further, widely used short-term 
TAB LE 2 Common adaptive responses in fisheries (Table S4 defines response types and forms)

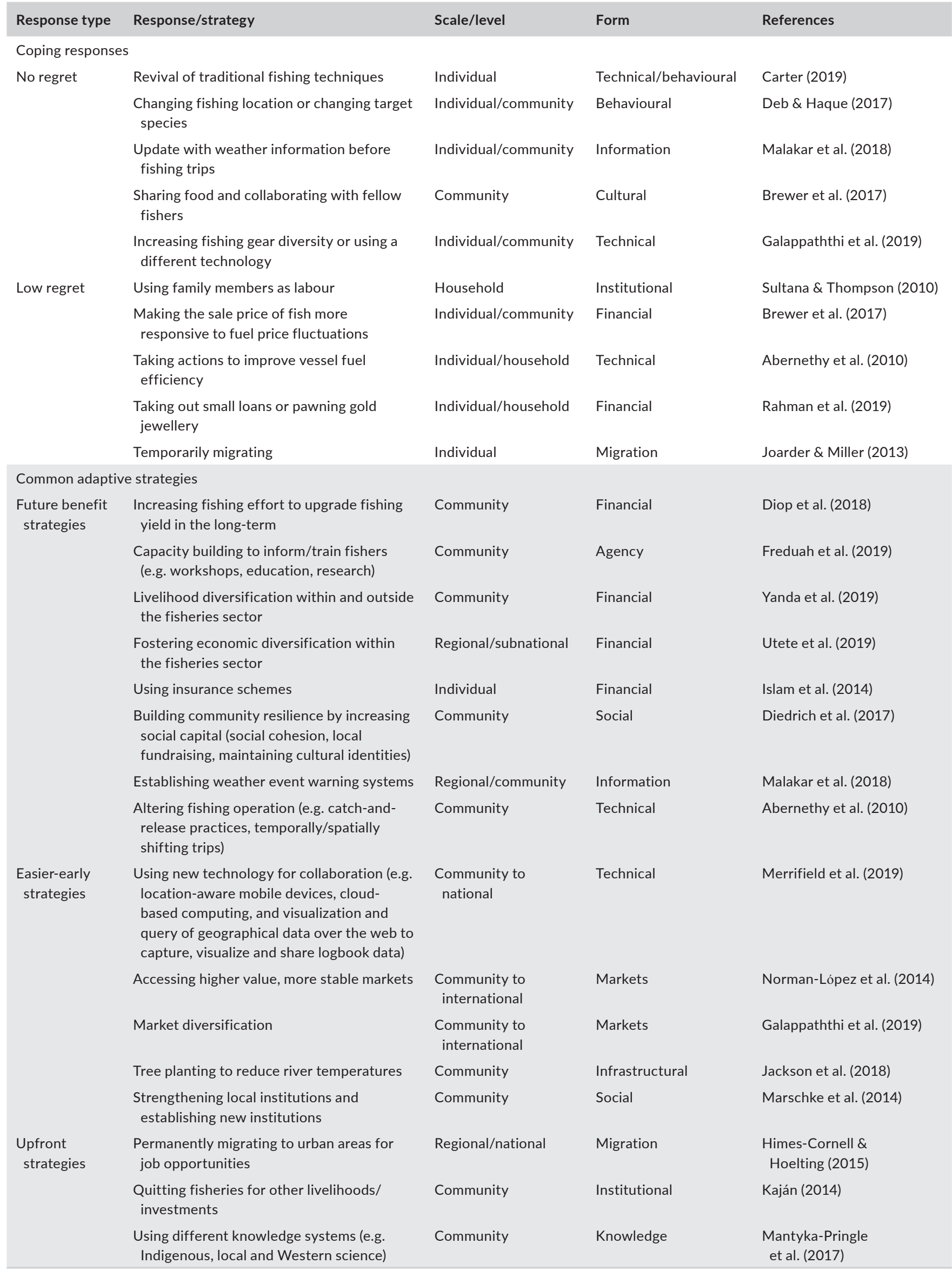


responses are informal and temporary livelihood options such as sharing fish (for food) and fishing-related information, compromising (or switching) gender roles in fisheries and using traditional fishing techniques.

\subsection{Adaptive strategies in fisheries}

Adaptive strategies are long-term responses or shifts in livelihood strategies in response to multiple stressors, including climate change (Marschke \& Berkes, 2006). Twenty-two per cent of studies were analysed and documented adaptive strategies of fisheries systems at various scales (community, regional and national) (Table 2). Many of these strategies (74\%) are from 23 global south countries, the top three of which were Bangladesh, India and Ghana. Global north countries include the USA, Canada and Australia. For instance, 33\% of the studies are led by North American institutions, yet only $25 \%$ of these papers target adaptation strategies in North America. We identified a diverse range of adaptive strategies. For example, modifications of fishing operations, adaptive capacity building, income diversification, ecosystem-based approaches, change in rules and regulations, community involvement, migration, and application of modern and traditional knowledge systems.

We found that documented adaptive strategies are responding to multiple climate change impacts such as extreme events $(n=9)$, climate variability $(n=3)$ and temperature increases $(n=1)$ (Table S5). For example, to respond to climate variability and atmospheric warming in Lake Wamala fisheries in Uganda, Musinguzi et al. (2016) found fishers apply multiple strategies such as livelihood diversification, traditional knowledge, increasing access to climate information and shifting gender roles in fisheries. Further, Galappaththi et al. (2019) found fishers use community adaptive responses, such as new technology, collective action, and collaboration, and combine different kinds of knowledge systems in Arctic Char (Salvelinus alpinus, Salmonidae) and Greenland Halibut (Reinhardtius hippoglossoides, Pleuronectidae) fisheries undergoing rapid social-ecological change in the Canadian Arctic. We also found adaptive strategies responding to specific climate impacts. For example, Chaijaroen (2019) found communities are switching to non-fisheries industries in response to long-lasting income shocks related to coral bleaching in Indonesian coastal fisheries. Also, Sultana and Thompson (2010) found that the creation of social influence through local institutions to the Flood Action Plan is a viable strategy for floodplain management in Bangladesh.

Many of the recorded fisheries are responding to multiple stressors using a combination of multiple adaptive strategies. For instance, numerous strategies were developed and implemented by the management authorities of the Peruvian anchovy (Engraulis ringens, Engraulidae) fishery to deal with anchovy stock variations due mainly to El Niño Southern Oscillation and serious warming events. Some of these strategies are intended to improve the geographical distribution of fish processing plants at different sites along the coast to address changes in the distribution of anchovy shoals; use low-cost unloading facilities; and implement rapid and flexible management programmes to improve out-of-date fisheries regulations (Arias Schreiber et al., 2011). Furthermore, Sarkar et al. (2018) found fishers applied six Indigenous adaptive strategies to improve floodplain fisheries management in West Bengal, India. These six climatesmart fishery strategies are (i) temporary pre-summer enclosure, (ii) submerged branch pile (Kata) refuge, (iii) autumn stocking, (iv) torchlight fishing, (v) deep pool (Komor) refuge and (vi) floating aquatic macrophyte refuge fishery (Pana chapa).

\subsection{Management responses in fisheries}

We identified long-term collective responses that involve planning, coordinating, organizing and monitoring at various scales that support climate adaptation as management responses (Table 3). We found that documented management responses are specifically responding to general climate change impacts $(n=50)$, ocean conditions $(n=14)$, climate variability $(n=5)$, fishery dynamics $(n=5)$, species distribution $(n=5)$ and temperature increases $(n=6)$ (Table S5). Among these studies (31\%, $n=71$ ), we identified four key management approaches, which are adaptive management, adaptation planning, community-based management and government support (including co-management).

Adaptive management is recorded largely $(n=38)$ at multiple levels (community to national) in marine, freshwater and brackish water fisheries in various forms, such as ecosystem-based management, precautionary management for resilient ecosystems, implementation of integrated adaptive management and integrated coastal management (d'Armengol et al., 2018). Adaptation planning is the second most recorded management approach, yet the majority of planning is recorded from global north countries (with the exception being Thailand), such as the USA, Germany, Norway, Australia and Spain. Adaptation planning is recorded mostly as a participatory process co-led by the municipal- to national-level government actors, with the various levels of community involvement (Pearce et al., 2012). Community-based management approaches are limited $(n=12)$ but recorded across different types of fisheries in the global north and south. Community-based management/adaptation occurs when locals respond to climate impacts using a bottom-up systematic approach that employs collective action and collaboration (implementation of flexible fishery control rules through community-based institutions; Hung et al., 2018). Government support in the fisheries setting comes in various forms, such as formal collaborative management (co-management), adaptive co-management and adaptive co-governance, for example, strengthening existing local management institutions and established new community organizations (Fidelman et al., 2017). These regional-level studies $(n=7)$ are limited to Canada, the USA, Australia, South Africa and Brazil. Most of these studies show the use of multiple management responses at the same time to respond to multiple climate change impacts (e.g. integration of community-based management with co-management).

Moreover, we found many other management approaches and terms used for climate adaptation in fisheries, such as the use of 
TABLE 3 Common management responses in fisheries

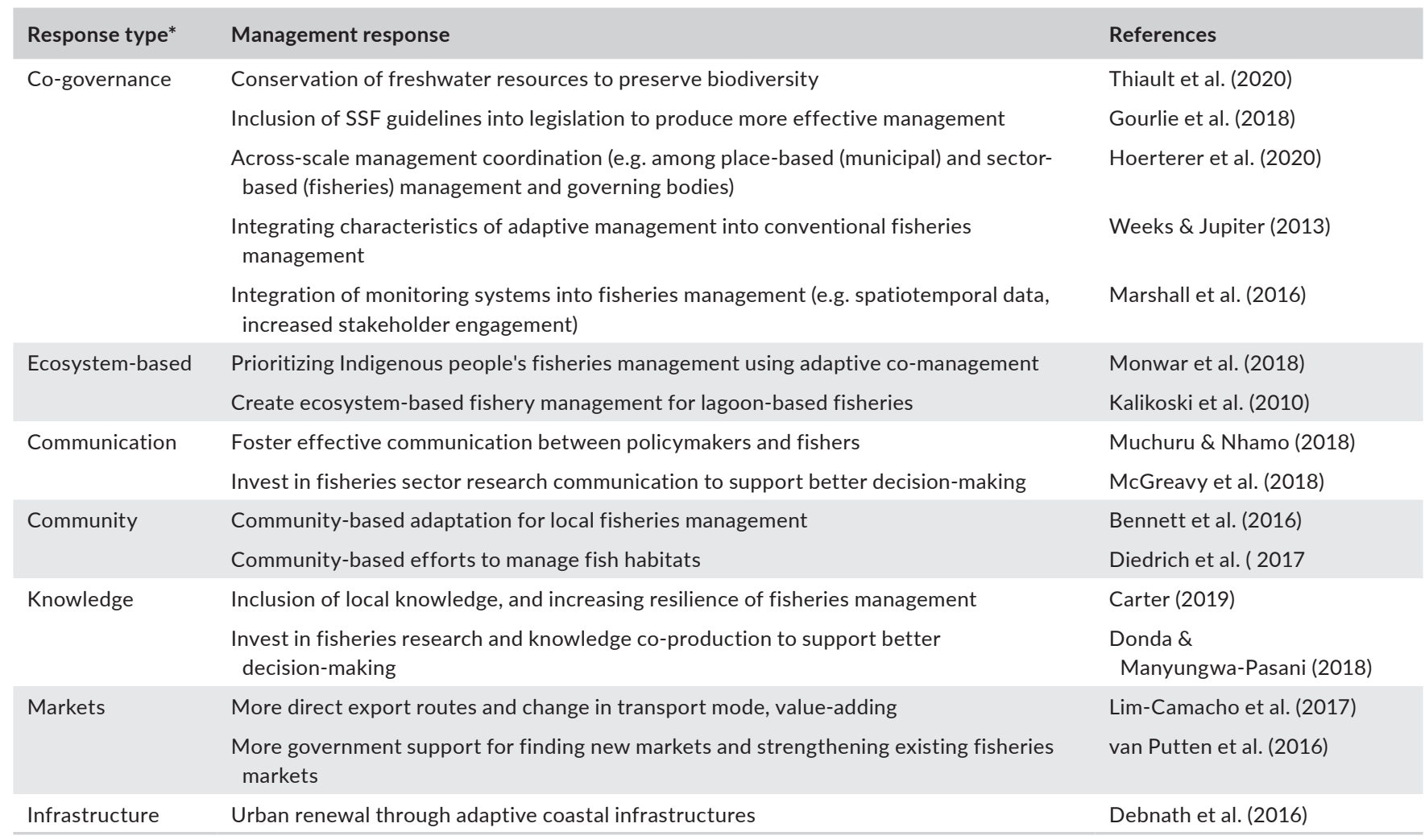

${ }^{*}$ The idea of climate-ready fisheries management overlaps with multiple response types.

adaptive institutions, ecosystem-based management, climate-ready fisheries management, monitoring and evaluation, adaptation processes, and adaptation measures and pathways. For example, in response to climate change impacts and multiple stressors, Schemmel et al. (2016) found a low-cost and low-tech community-based fish monitoring approach to assess the seasonal spawning peaks, lunar spawning cycles and size at maturity for key targeted reef fish in Hawaiian reef fisheries.

\subsection{Limits to adaptation in fisheries}

Limits, barriers and constraints to adaptation will restrict the adaptive responses of fisheries systems and their ability to address the negative impacts of climate change. Over 35\% of articles mentioned various aspects related to limits, and we placed commonly recorded limits into six categories: place, agency, collective action and collaboration (societal), institutions, knowledge systems and learning (Table 4). Yet, there are limited articles studying limits as their primary focus. For example, Whitney and Ban (2019) found the importance of recognizing governance and policy-related barriers when incorporating climate change adaptation into the marine protected area management and planning in British Columbia. Additionally, Islam et al. (2014) found five forms of obstacles to the adaptation of fishing activities to cyclones in Padma and Kutubdia Para Bangladeshi coastal fishing communities: natural, technological, social, economic and formal institutional.

\section{9 | Policy contributions}

Seventy-nine per cent $(n=182)$ of studies address the specific aspects of policy implications related to climate adaptations in fisheries. Many of these (56\%) articles refer to policy in general. For example, Belhabib et al. (2014) found how illegal fishing in coastal Senegal leads to the misrepresentation of fish catch data. This article does not directly address the policy implications of inaccurate catch data for climate adaptation, yet indirectly generates policy insights. We found a limited number of studies that address specific policy implications. For example, Khan et al. (2018) found how municipal adaptation policy initiatives can complement sector-based adaptation policy at both local and regional levels through various entry points across commodity production chains in Canada. These policy integrations across place-based and sector-based adaptation processes can lead to multiple benefits such as conserving marine biodiversity, protecting essential infrastructure and securing fisheries livelihoods. Further, Barragán and Lazo (2018) found 10 key elements of the national coastal management policy in the context of climate change adaptation in the context of integrated coastal zone management in Peru: policy, institutions, normative management, instruments, information, education, strategies, resources, managers and participation. 
TAB LE 4 Commonly recorded limits to climate adaptation in fisheries

\begin{tabular}{|c|c|c|c|}
\hline Category & Examples for limits & Implications of limits & References \\
\hline Human agency & $\begin{array}{l}\text {-financial capital } \\
\text {-limited access and affordability to } \\
\text { advanced technology } \\
\text {-lack of access to credit }\end{array}$ & $\begin{array}{l}\text { Lack of financial resources, } \\
\text { technology and assets will increase } \\
\text { their exposure and vulnerability to } \\
\text { climate change }\end{array}$ & $\begin{array}{l}\text { Islam et al. (2014), Merrifield et al. (2019), } \\
\text { Mohamed-Shaffril et al. (2017) }\end{array}$ \\
\hline Societal & $\begin{array}{l}\text {-communication and information } \\
\text { sharing barriers } \\
\text {-cultural barriers to collaboration and } \\
\text { sharing } \\
\text {-tragedy of the fisheries commons }\end{array}$ & $\begin{array}{l}\text { Specific social norms, beliefs and } \\
\text { cultural values limit social reciprocity } \\
\text { and cohesiveness, determining } \\
\text { the effectiveness of adaptation } \\
\text { responses }\end{array}$ & $\begin{array}{l}\text { Blanco et al. (2015), Makame \& } \\
\text { Shackleton (2020), Weir et al. (2017 }\end{array}$ \\
\hline $\begin{array}{l}\text { Knowledge } \\
\text { systems }\end{array}$ & $\begin{array}{l}\text {-weaken traditional knowledge } \\
\text { systems } \\
\text {-lack of knowledge co-production } \\
\text { efforts } \\
\text {-lack of education, training and } \\
\text { research }\end{array}$ & $\begin{array}{l}\text { Weakening of knowledge systems } \\
\text { and limited access to updates can } \\
\text { prevent engagement with adaptive } \\
\text { responses }\end{array}$ & $\begin{array}{l}\text { Carter (2019), Mantyka-Pringle et al. } \\
\text { (2017), Seithi et al. (2011) }\end{array}$ \\
\hline Learning & $\begin{array}{l}\text {-limited access to learning } \\
\text { opportunities } \\
\text {-lack of capacity-building opportunities } \\
\text { for co-learning } \\
\text {-communication limits and information } \\
\text { gaps in local fisheries }\end{array}$ & $\begin{array}{l}\text { Lack of learning opportunities and } \\
\text { communication barriers can create } \\
\text { barriers for co-learning, learning-by- } \\
\text { doing and effective communication, } \\
\text { which are integral to successful } \\
\text { adaptive responses }\end{array}$ & $\begin{array}{l}\text { Brewer et al. (2017), Hoerterer et al. } \\
\text { (2020), Whitney \& Ban (2019) }\end{array}$ \\
\hline
\end{tabular}

\subsection{0 | Grey literature assessment}

Our grey literature includes professional reports and conference proceedings with a broader scope of study aims (e.g. market and value chain, mixed systems, social-cultural, livelihoods and fish catches), which further contextualized this study. The results summarized below show that the grey literature extended the findings given in the peer-reviewed assessment and had similar outcomes. In terms of target fisheries, marine fisheries are the most studied (>80\%) among grey literature, while inland (12\%) and brackish (7\%) systems are studied less.

Most of the studies used multiple or integrated theoretical approaches (>30\%), followed by management (28\%), anthropogenic (16\%), systems (14\%) and economic (11\%). We found that most documented climate change impacts are general climate impacts (40\%) or multiple stressors (38\%). Climate impacts related to ocean conditions (14\%) and climate variability $(10 \%)$ are also recorded in grey literature. For instance, Mulyasari et al. (2018) reported perceptions and local adaptation strategies responding to general climate impacts in marine capture fisheries in Bengkulu Province, Indonesia.

Many of the grey literature did not assess coping responses (65\%). Documented types of coping responses are most like the results of the peer-review assessment (e.g. increasing fishing time/ distance and changing fishing species). Over half of all the studies used multiple adaptive strategies. One-third of the documented adaptive strategies are related to building adaptive capacity (e.g. strengthening assets, improving information sharing). Other documented adaptive strategies are scattered among various categories, including significant changes in fishing operation, adjustments in fisheries management rules and regulations, livelihood diversification and the use of multiple adaptive strategies. In terms of management responses, grey literature heavily discussed six types. We found that the use of multiple management strategies (e.g. community-based adaptation and co-management) was the most (28\%) documented. The rest of the management responses were co-management (19\%), ecosystem-based management (15\%), community-based management (15\%), adaptive management (15\%) and adaptation planning (9\%). For example, Johnson et al. (2019) report various adaptation responses from 27 research locations across the globe include the use of local knowledge, capacity building and adaptive institutions.

We found that climate adaptation limits are rarely discussed in grey literature. When they are discussed, limits related to institutions (e.g. inadequate regulations), human agency (e.g. limited management capacities), knowledge systems (e.g. information barriers) 
and learning (e.g. access to education) are documented themes. For instance, Barange et al. (2018) report that poor enforcement systems are a barrier for adaptation in fisheries. Most grey literature (72\%) did not assess policy recommendations. Twenty-eight per cent of studies address the specific aspects of policy implications related to climate adaptations in fisheries.

\section{4 | DISCUSSION}

This paper systematically assesses the state of the peer-reviewed literature on global climate change adaptation in a fisheries context. Many intergovernmental reports continue to demonstrate the importance of fisheries in providing food, nutrition and food security (Barange et al. 2018; FAO, 2020; IPCC, 2018). Based on peerreviewed empirical evidence on climate adaptation $(n=230)$, we advance understanding to inform the ongoing and future fisheries adaptation efforts and policy. Many of these studies are initiated and funded by three countries: the USA, Australia and Canada. Our results reveal both mismatches and complementarities with other literature. For instance, the top marine species catches in 2018 are Anchovies (Engraulis ringens), Alaska Pollock (Gadus chalcogrammus) and Skipjack Tuna (Katsuwonus pelamis) (FAO, 2020), while the most studied species groups in climate adaptation are Lobster, Tuna and Cod. These studies focus mostly on how fisheries support livelihoods and the sector's importance for food systems. Many studies that focus on the human dimensions of climate adaptation do not have a species focus to investigate climate impacts and adaptation responses.

Global fisheries systems adapt to a wide range of climate change impacts (Figure 4). Our findings support the previous global assessment reports of climate change impacts and aquatic systems (Barange \& Cochrane, 2018; Kalikoski et al. 2018). For example, Bahri et al. (2018) synthesized the implications of climate impacts in aquatic systems, including water temperature, oxygen content, ice coverage, sea level, ocean circulation, ocean acidification and primary production. We identified three types of documented ways in which people experience climate change impacts in a fisheries setting: multiple simultaneous impacts (e.g. extreme weather events and sea-level rise); interrelated and mixed impacts (e.g. economic and market volatility in the context of climate variability); and geographically specific effects (e.g. sea-level rise in Pacific Islands, sea ice melting in the Arctic). Most peer-reviewed literature published between 1990 and 2019 examining climate impacts has a strong focus on marine ecosystems and devotes less attention to the human dimensions of climate impacts. For example, Brander (2010) identified direct and indirect climate impacts on fisheries by investigating physical and chemical factors in marine systems. It is also notable that this review did not identify overfishing as a major stressor that interacts with climate change and influences adaptive capacity and adaptation options (Sumaila \& Tai, 2020).

We categorized three critical ways of responding to climate change impacts in the global fisheries setting: (i) coping mechanisms, (ii) adaptive strategies and (iii) management approaches for adaptation. Coping responses are practised mainly by fishers across the world to deal with the various climate impacts at the local level (e.g. behavioural responses such as changing fishing location). These responses were recorded from a diverse range of geographical regions (e.g. Honduras, India, the USA, Cambodia, French Polynesia and Ghana). Coping responses are characterized by their short-term nature, the autonomous nature of reactions, low/no-regret-type responses and a technical focus. Further, most coping mechanisms respond to specific climate change impacts, responding to multiple- or mixed-effects (e.g. Southern USA oyster industry looking for new harvesting locations to deal with flooding, erosion, and increased saltwater intrusion). Previous synthesis exercises and grey literature have also recognized coping mechanisms in the fisheries and aquaculture setting (Barange et al. 2018). Both peer-reviewed literature and grey literature indicate the indistinct difference between recorded coping and adaptive strategies (Dzantor et al., 2020; Johnson et al., 2019). Coping responses must be complemented by the adaptive strategies and management responses to build resilience in fisheries.

Second, we identified diverse adaptive strategies in global fisheries to deal with the implications of climate change impacts. More geographically generalizable adaptive strategies include livelihood diversification (within and outside fisheries), technology and the modification of fishing activities (e.g. fishing gear, target species), investments in physical capital (e.g. infrastructure), insurance, the preservation and application of traditional and local knowledge systems, the improvement of community involvement (e.g. communitybased resource monitoring), the addressing of information gaps, and education and training. Also, we identified place-specific adaptation strategies (Khan et al., 2018), including migration, early warning systems, changes in markets, and the integration of Indigenous and local knowledge for decision-making. These adaptive strategies are compatible with the documented adaptations in the grey literature assessment, which includes the previous global fisheries and aquaculture assessments led by the FAO (Barange et al. 2018; Daw et al. 2009).

Third, we found four management approaches used in response to climate change impacts: (i) adaptive management, (ii) adaptation planning, (iii) community-based management and (iv) government support (including co-management). These recorded management responses are key to generating and supporting coping efforts at the local level and adaptive strategies at multiple levels (community to global) through multi-level institutions and actors (Daw et al. 2009; Koontz et al., 2015). Most of these responses (Table 3) are related to widely documented management responses in other sectors and the climate change adaptation literature in general (Galappaththi et al., 2020; Miller et al., 2018; Paukert et al., 2016). For example, in terms of the recorded number of studies, adaptive management emerges as the most dominant management response in fisheries, whereas Galappaththi et al. (2020) found adaptation planning to be the most prominent in the aquaculture sector following communitybased adaptation. We were also surprised at how some of the 
themes, such as climate-ready fisheries management, are not highlighted in the systematic review (Bell et al., 2020).

We identified three characteristics of adaptive strategies and management responses: (i) applied in a multi-level context (community to global/mostly top to bottom), (ii) of a long-term nature (bring present and future benefits) and (iii) responds to a large range of climate impacts (sometimes across sectors). For example, to align with the National Flood Action Plan, Bangladesh has established new local institutions for flood management building on community-level fisheries organizations (Sultana \& Thompson, 2010). Yet, practising on the ground is not limited to the identified responses in the study. Adaptation can be seen as an ongoing and iterative social process (Wolf, 2011). The progress and effectiveness of adaptation responses are influenced by the geographical, environmental, institutional and socio-economic contexts of specific fisheries; they could also rely on current adaptation progress at various levels (Barange et al. 2018; Lesnikowski et al., 2016). Also, new or modified regulations, policies (e.g. FAO fisheries guidelines) and their enforcement are integral parts of successful climate adaptation and sustainable fisheries management (Hilborn, 2007; Selig et al., 2017).

\section{5 | OPPORTUNITIES AND DIRECTIONS FOR FUTURE RESEARCH}

A systematic review like this is often used to understand and communicate significant research gaps, thereby identifying future research opportunities. Our study is based on 230 peer-reviewed articles chosen using a specific selection criterion (Section 2). To our knowledge, limited systematic review assessments aimed at climate change adaptation in fisheries (excluding aquaculture) are available. Thus, the area of climate change adaptation in fisheries has the potential for further development in various aspects. For example, according to the FAO data, the top five producers for capture fisheries are China (15\%), Indonesia (7\%), Peru (7\%), India (6\%) and Russia (5\%), comprising up to $40 \%$ (>38 million tonnes) of the global production (FAO, 2020). In our study, these five countries are not among the top five research destination countries (except India) and represent only $11 \%$ ( 25 articles out of 230 ) of the sample (India dominates with 15 studies).

We identified gaps related to theoretical and methodological approaches adopted to study climate change adaptation in fisheries. We identified three conceptual gap areas based on the Venn diagram analysis (Figure 3), which used four conceptual categories (i.e. systems, management, economics and anthropogenic). First, we identified the gap in the overlapping area of management, systems and economics. Second, there is an opportunity to link various anthropogenic approaches with management approaches. Third, there is a large gap for conceptual integration among the four identified thematic conceptual areas and beyond. Though FAO (2015) investigates theoretical frameworks and methodologies available to examine climate change adaptation in fisheries and aquaculture, we identified gaps in methodological approaches for future research. We found a dearth of quantitative studies for climate adaptation in fisheries. Many of the studies were built on primary data; thus, there is a gap for studies using secondary data and a mix of primary and secondary data.

We identified various opportunities for future research in different types of fisheries (i.e. marine, inland and brackish). Inland and brackish water fisheries have limited studies compared to marine fisheries, which apply across the globe. For example, Oceania represents a relatively limited number of inland and brackish water studies as compared to marine fisheries, which warrants further empirical attention. Results indicate that Europe also requires further attention with regard to inland fisheries. Both Asia and North America have low numbers of inland and brackish fisheries studies. Further, we identified a lack of explicit typology for global fisheries types in climate adaptation that could limit the effective scaling-up of empirical lessons up to global adaptation policy. Currently, global fisheries types are characterized in many ways, for example, sizespecific (e.g. small-scale, large-scale), economic purpose (e.g. subsistence, commercial), species-specific (e.g. lobster or tuna fisheries), geographical specific (e.g. Mbenje Island fishery, gulf fisheries) and gear-specific (e.g. trawl fisheries).

The ways in which the fisheries sector experiences climate change impacts in an adaptation context are not well studied. Our analysis indicates specific categories of climate impacts require more scholarly attention in particular regions, such as fish species distribution (from a human dimension perspective) in Asia, Oceania and South America. Also, marine system shifts in South America and Africa, extreme climate events in Oceania and general climate change impacts in South America are understudied. We presume that regions such as South America might have more relevant documented knowledge, but this knowledge is inaccessible due to language barriers. The climate change impacts in the global fisheries adaptation context should be continuously monitored because of the dynamic and complex nature of climate change implications and the vulnerable fisheries populations. That being said, various FAO reports have studied these impacts aimed at fisheries and aquaculture (Barange et al. 2018; FAO, 2015; Johnson et al., 2019; Seggel \& De Young, 2016).

We found various adaptive responses documented across the globe, but limited attention has been paid to examining barriers, constraints and limits for climate adaptation. Our study identified very little evidence on adaptation limits as a primary study focus (Islam et al., 2014; Whitney \& Ban, 2019). We were able to analyse widely documented limitations across studies. We believe that there is an opportunity to specifically assess global adaptation limits in fisheries to inform climate change adaptation policy. Additionally, we identified specific study areas that require attention in future research. There is a clear gap in which to carry out comparative case studies to generate broader adaptation insights. Marginalized and underrepresented fisher populations such as Indigenous fisheries must be further investigated given the potentially high vulnerability of such fisheries systems. It is also important to synthesize and 
assess ongoing and past empirical knowledge to inform global fisheries adaptation.

Overall, much more attention and resources are likely needed to support the fisheries sector in adapting to ongoing and future climate change. Our study highlights how climate change impacts can affect fisheries systems and adaptation responses that can affect global fisheries production. An inability to adapt and a decrease in fisheries production have implications for the industry, as well as for a growing world population, as it is associated with food security (Béné et al., 2016; Loring et al., 2019). Non-climatic stressors such as COVID-19 further complicate the implications of climate change and create barriers for adaptation activities (Bennett et al., 2020). With the acknowledgement that the fishing sector may not be able to adapt to all the impacts of climate change, it is essential to continue assessments and improve climate change adaptation research in fisheries.

\section{ACKNOWLEDGEMENTS}

EKG acknowledges the financial support of the doctoral fellowship of the Social Science and Humanities Research Council (SSHRC) of Canada. STI acknowledges the financial support of a graduate research assistantship through the AquaFish Innovation Lab at Oregon State University. AAH acknowledges the financial support of an assistantship through the Department of Ecology and Evolutionary Biology at the University of Tennessee, Knoxville.

\section{ORCID}

Eranga K. Galappaththi iD https://orcid. org/0000-0002-3926-2206

Vasantha B. Susarla (iD https://orcid.org/0000-0002-2152-7843

Samantha J. T. Loutet (iD https://orcid.org/0000-0001-7677-0982

Stephanie T. Ichien (D) https://orcid.org/0000-0002-9288-7301

Amanda A. Hyman iD https://orcid.org/0000-0002-3317-4774

James D. Ford (D) https://orcid.org/0000-0002-2066-3456

\section{REFERENCES}

Abernethy, K. E., Trebilcock, P., Kebede, B., Allison, E. H., \& Dulvy, N. K. (2010). Fuelling the decline in UK fishing communities? ICES Journal of Marine Science, 67, 1076-1085. https://doi.org/10.1093/icesjms/ fsp289

Arias Schreiber, M., Ñiquen, M., \& Bouchon, M. (2011). Coping strategies to deal with environmental variability and extreme climatic events in the Peruvian Anchovy Fishery. Sustainability, 3, 823-846. https:// doi.org/10.3390/su3060823

Bahadur, K. K., Seng, R., \& Fraser, E. (2019). Should I stay or should I go? Fishers' ability and willingness to adapt to environmental change in Cambodia's Tonle Sap Lake. Fisheries Management and Ecology, 26(3), 211-223. https://doi.org/10.1111/fme.12341

Bahri, T., Barange, M., \& Moustahfid, H. (2018). Climate change and aquatic systems. In M. Barange T. Bahri M.C. Beveridge K.L. Cochrane S. Funge-Smith \& F. Poulain (Eds.), Impacts of climate change on fisheries and aquaculture: Synthesis of current knowledge, adaptation and mitigation options. FAO Fisheries and Aquaculture Technical Paper No. 627: pp. 1-17.

Barange, M., Bahri, T., Beveridge, M. C., Cochrane, K. L., Funge-Smith, S., \& Poulain, F. (2018). Impacts of climate change on fisheries and aquaculture, Synthesis of current knowledge, adaptation and mitigation options. Food and Agriculture Organization of the United Nations, FAO Fisheries and Aquaculture Technical Paper No. 627: 628 pp.

Barange, M., \& Cochrane, K. L. (2018). Impacts of climate change on fisheries and aquaculture: Conclusions. In M. Barange (Ed.), Impacts of climate change on fisheries and aquaculture: Synthesis of current knowledge, adaptation and mitigation options. FAO Fisheries and Aquaculture Technical Paper No. 627: pp. 611-628.

Barragán, J. M., \& Lazo, Ó. (2018). Policy progress on ICZM in Peru. Ocean \& Coastal Management, 157, 203-216. https://doi.org/10.1016/j. ocecoaman.2018.03.003

Belhabib, D., Koutob, V., Sall, A., Lam, V. W., \& Pauly, D. (2014). Fisheries catch misreporting and its implications: The case of Senegal. Fisheries Research, 151, 1-11. https://doi.org/10.1016/j.fishres.2013.12.006

Bell, R. J., Odell, J., Kirchner, G., \& Lomonico, S. (2020). Actions to Promote and Achieve Climate-Ready Fisheries: Summary of Current Practice. Marine and Coastal Fisheries, 12, 166-190. https://doi. org/10.1002/mcf2.10112

Béné, C., Arthur, R., Norbury, H., Allison, E. H., Beveridge, M., Bush, S., Campling, L., Leschen, W., Little, D., Squires, D., Thilsted, S. H., Troell, M., \& Williams, M. (2016). Contribution of fisheries and aquaculture to food security and poverty reduction: Assessing the current evidence. World Development, 79, 177-196. https://doi.org/10.1016/j. worlddev.2015.11.007

Bennett, N. J., Finkbeiner, E. M., Ban, N. C., Belhabib, D., Jupiter, S. D., Kittinger, J. N., Mangubhai, S., Scholtens, J., Gill, D., \& Christie, P. (2020). The COVID-19 pandemic, small-scale fisheries and coastal fishing communities. Coastal Management, 48, 336-347. https://doi. org/10.1080/08920753.2020.1766937

Bennett, N., Kadfak, A., \& Dearden, P. (2016). Community-based scenario planning: A process for vulnerability analysis and adaptation planning to social-ecological change in coastal communities. Environment Development and Sustainability, 18, 1771-1799. https:// doi.org/10.1007/s10668-015-9707-1

Berrang-Ford, L., Pearce, T., \& Ford, J. D. (2015). Systematic review approaches for climate change adaptation research. Regional Environmental Change, 15, 755-769. https://doi.org/10.1007/s1011 3-014-0708-7

Bindoff, N. L., Cheung, W. W., Kairo, J. G., Arístegui, J., Guinder, V. A., Hallberg, R., Hilmi, N. J. M., Jiao, N., Karim, M. S., Levin, L., O'Donoghue, S., Purca Cuicapusa, S. R., Rinkevich, B., Suga, T., Tagliabue, A., \& Williamson, P. (2019). Changing ocean, marine ecosystems, and dependent communities. In IPCC special report on the ocean and cryosphere in a changing climate (pp. 477-587). Intergovernmental Panel on Climate Change.

Blanco, E., Lopez, M. C., \& Villamayor-Tomas, S. (2015). Exogenous degradation in the commons: Field experimental evidence. Ecological Economics, 120, 430-439. https://doi.org/10.1016/j.ecole con.2015.03.028

Brander, K. (2010). Impacts of climate change on fisheries. Journal of Marine Systems, 79, 389-402. https://doi.org/10.1016/j.jmars ys.2008.12.015

Brewer, J. F., Molton, K., Alden, R., \& Guenther, C. (2017). Accountability, transformative learning, and alternate futures for New England groundfish catch shares. Marine Policy, 80, 113-122. https://doi. org/10.1016/j.marpol.2016.09.015

Camargo, C., Maldonado, J. H., Alvarado, E., Moreno-Sánchez, R., Mendoza, S., Manrique, N., Mogollón, A., Osorio, J. D., Grajales, A., \& Sánchez, J. A. (2009). Community involvement in management for maintaining coral reef resilience and biodiversity in southern Caribbean marine protected areas. Biodiversity and Conservation, 18, 935-956. https://doi.org/10.1007/s10531-008-9555-5

Carter, L. (2019). He korowai o Matainaka/The cloak of Matainaka. New Zealand Journal of Ecology, 43, 1-8. https://doi.org/10.20417/nzjec ol.43.27 
Chaijaroen, P. (2019). Long-lasting income shocks and adaptations: Evidence from coral bleaching in Indonesia. Journal of Development Economics, 136, 119-136. https://doi.org/10.1016/j.jdeve co.2018.10.002

Cisneros-Montemayor, A. M., Pauly, D., Weatherdon, L. V., \& Ota, Y. (2016). A global estimate of seafood consumption by coastal indigenous peoples. PLoS One, 11, e0166681. https://doi.org/10.1371/ journal.pone.0166681

Codjoe, S. N. A., Atidoh, L. K., \& Burkett, V. (2012). Gender and occupational perspectives on adaptation to climate extremes in the Afram Plains of Ghana. Climatic Change, 110, 431-454. https://doi. org/10.1007/s10584-011-0237-z

Collin, A., Nadaoka, K., \& Bernardo, L. (2015). Mapping the SocioEconomic and Ecological Resilience of Japanese Coral Reefscapes across a Decade. ISPRS International Journal of Geo-Information, 4, 900-927. https://doi.org/10.3390/ijgi4020900

d'Armengol, L., Castillo, M. P., Ruiz-Mallén, I., \& Corbera, E. (2018). A systematic review of co-managed small-scale fisheries: Social diversity and adaptive management improve outcomes. Global Environmental Change, 52, 212-225. https://doi.org/10.1016/j.gloen vcha.2018.07.009

Daw, T., Adger, W. N., Brown, K., \& Badjeck, M. C. (2009). Climate change and capture fisheries: Potential impacts, adaptation and mitigation. In K. Cochrane, C. De Young, D. Soto, \& T. Bahri (Eds.), Climate change implications for fisheries and aquaculture: Overview of current scientific knowledge. FAO Fisheries and Aquaculture Technical Paper. No. 530. pp. 107-150.

de Coninck, H., Revi, A., Babiker, M., Bertoldi, P., Buckeridge, M., Cartwright, A., Dong, W., Ford, J., Fuss, S., Hourcade, J.-C., Ley, D., Mechler, R., Newman, P., Revokatova, A., Schultz, S., Steg, L., \& Sugiyama, T. (2018). Strengthening and implementing the global response. In: V. Masson-Delmotte, P. Zhai, H.-O. Pörtner, D. Roberts, J. Skea, P. R. Shukla, A. Pirani, W. Moufouma-Okia, C. Péan, R. Pidcock, S. Connors, J. B. R. Matthews, Y. Chen, X. Zhou, M. I. Gomis, E. Lonnoy, T. Maycock, M. Tignor, \& T. Waterfield (eds.) Global Warming of $1.5^{\circ} \mathrm{C}$. An IPCC Special Report on the impacts of global warming of $1.5^{\circ} \mathrm{C}$ above pre-industrial levels and related global greenhouse gas emission pathways, in the context of strengthening the global response to the threat of climate change, sustainable development, and efforts to eradicate poverty. In Press. Online: Intergovernmental Panel on Climate Change.

IPCC. (2018). De Coninck, H., A. Revi, M. Babiker, P. Bertoldi, M. Buckeridge, A. Cartwright, W. Dong, J. Ford, S. Fuss, J.-C. Hourcade, D. Ley, R. Mechler, P. Newman, A. Revokatova, S. Schultz, L. Steg, and T. Sugiyama, 2018: Strengthening and Implementing the Global Response. In: V. Masson-Delmotte, P. Zhai, H.-O. Pörtner, D. Roberts, J. Skea, P. R. Shukla, A. Pirani, W. Moufouma-Okia, C. Péan, R. Pidcock, S. Connors, J. B. R. Matthews, Y. Chen, X. Zhou, M. I. Gomis, E. Lonnoy, T. Maycock, M. Tignor, \& T. Waterfield (eds.) Global Warming of $1.5^{\circ} \mathrm{C}$. An IPCC Special Report on the impacts of global warming of $1.5^{\circ} \mathrm{C}$ above pre-industrial levels and related global greenhouse gas emission pathways, in the context of strengthening the global response to the threat of climate change, sustainable development, and efforts to eradicate poverty. In Press. Online: Intergovernmental Panel on Climate Change.

Deb, A. K., \& Haque, C. E. (2017). Multi-dimensional coping and adaptation strategies of small-scale fishing communities of Bangladesh to climate change induced stressors. International Journal of Climate Change Strategies and Management, 9, 446-468. https://doi. org/10.1108/IJCCSM-06-2016-0078

Debnath, B., Krishnan, M., Ananthan, P., \& Debnath, B. (2016). Awareness, perceptions and adaptation strategies of women in urban fishing village in a climate change environment-a case study in Versova, Mumbai. Indian Journal of Fisheries, 63, 120-125. https:// doi.org/10.21077/ijf.2016.63.3.40077-17
Diedrich, A., Stoeckl, N., Gurney, G. G., Esparon, M., \& Pollnac, R. (2017). Social capital as a key determinant of perceived benefits of community-based marine protected areas. Conservation Biology, 31, 311-321. https://doi.org/10.1111/cobi.12808

Diop, B., Sanz, N., Duplan, Y. J. J., Guene, E. H. M., Blanchard, F., Pereau, J.-C., \& Doyen, L. (2018). Maximum economic yield fishery management in the face of global warming. Ecological Economics, 154, 52-61. https://doi.org/10.1016/j.ecolecon.2018.07.027

Donda, S., \& Manyungwa-Pasani, C. L. (2018). Understanding indigenous knowledge: Its role and potential in fisheries resources management in Malawi. Aquatic Ecosystem Health and Management, 21, 176-184. https://doi.org/10.1080/14634988.2018.1451187

Dubik, B. A., Clark, E. C., Young, T., Zigler, S. B. J., Provost, M. M., Pinsky, M. L., \& Martin, K. S. (2019). Governing fisheries in the face of change: Social responses to long-term geographic shifts in a US fishery. Marine Policy, 99, 243-251. https://doi.org/10.1016/j. marpol.2018.10.032

Dzantor, S. A., Aheto, D. W., \& Adeton, C. O. (2020). Assessment of Vulnerability and Coping Livelihood Strategies of Fishermen in Elmina, Ghana. East African Journal of Interdisciplinary Studies, 2, 7188. https://doi.org/10.37284/eajis.2.1.200

Ensor, J. E., Park, S. E., Attwood, S. J., Kaminski, A. M., \& Johnson, J. E. (2018). Can community-based adaptation increase resilience? Climate and Development, 10, 134-151. https://doi.org/10.1080/17565 529.2016.1223595

Etikan, I., Musa, S. A., \& Alkassim, R. S. (2016). Comparison of convenience sampling and purposive sampling. American Journal of Theoretical and Applied Statistics, 5(1), 1-4. https://doi.org/10.11648/ j.ajtas.20160501.11

Fairclough, N. (2013). Critical discourse analysis: The critical study of language, Vol. 2 (pp. 608). Routledge.

FAO (2015). Assessing Climate Change Vulnerability in Fisheries and Aquaculture: Available Methodologies and their Relevance for the Sector, by Cecile Brugère and Cassandra De Young. FAO Fisheries and Aquaculture Technical Paper, No. 597.

FAO (2018). The State of World Fisheries and Aquaculture 2018-Meeting the sustainable development goals. FAO. Licence: CC BY-NC-SA 3.0 IGO.

FAO (2019). FishStatJ - Software for Fishery and Aquaculture Statistical Time Series. Fisheries and Aquaculture Department, Food and Agriculture Organization of the United Nations. http://www.fao. org/fishery/statistics/software/fishstatj/en

FAO (2020). The State of World Fisheries and Aquaculture 2020. Sustainability in action. FAO. https://doi.org/10.4060/ca9229en

Fidelman, P., Van Tuyen, T., Nong, K., \& Nursey-Bray, M. (2017). The institutions-adaptive capacity nexus: Insights from coastal resources co-management in Cambodia and Vietnam. Environmental Science \& Policy, 76, 103-112. https://doi.org/10.1016/j.envsci.2017.06.018

Forbes, B. C. (2013). Cultural resilience of social-ecological systems in the Nenets and Yamal-Nenets Autonomous Okrugs, Russia: A focus on reindeer nomads of the tundra. Ecology and Society, 18, 36. https:// doi.org/10.5751/ES-05791-180436

Ford, J. D., \& Pearce, T. (2010). What we know, do not know, and need to know about climate change vulnerability in the western Canadian Arctic: A systematic literature review. Environmental Research Letters, 5, 014008. https://doi.org/10.1088/1748-9326/5/1/014008

Frawley, T. H., Crowder, L. B., \& Broad, K. (2019). Heterogeneous perceptions of social-ecological change among small-scale fishermen in the central Gulf of California: Implications for adaptive response. Frontiers in Marine Science, 6, 78. https://doi.org/10.3389/ fmars.2019.00078

Freduah, G., Fidelman, P., \& Smith, T. F. (2019). Adaptive capacity of small-scale coastal fishers to climate and non-climate stressors in the Western region of Ghana. The Geographical Journal, 185, 96-110. https://doi.org/10.1111/geoj.12282 
Galappaththi, E. K., Ford, D. J., Bennett, E. M., \& Berkes, F. (2019). Climate change and community fisheries in the Arctic: A case study from Pangnirtung, Canada. Journal of Environmental Management, 250(109534), 11. https://doi.org/10.1016/j.jenvman.2019.109534

Galappaththi, E. K., Ichien, S. T., Hyman, A. A., Aubrac, C. J., \& Ford, J. D. (2020). Climate change adaptation in aquaculture. Reviews in Aquaculture, 12, 2160-2176. https://doi.org/10.1111/raq.12427

Gammage, L. C., Jarre, A., \& Mather, C. (2017). A case study from the southern Cape line fishery 2: Considering one's options when the fish leave. South African Journal of Science, 113, 1-10. https://doi. org/10.17159/sajs.2017/20160254

Gourlie, D., Davis, R., Govan, H., Marshman, J., \& Hanich, Q. (2018). Performing "A New Song": Suggested considerations for drafting effective coastal fisheries legislation under climate change. Marine Policy, 88, 342-349. https://doi.org/10.1016/j.marpol.2017.06.012

Hilborn, R. (2007). Managing fisheries is managing people: What has been learned? Fish and Fisheries, 8, 285-296. https://doi. org/10.1111/j.1467-2979.2007.00263_2.x

Himes-Cornell, A., \& Hoelting, K. (2015). Resilience strategies in the face of short-and long-term change: Out-migration and fisheries regulation in Alaskan fishing communities. Ecology and Society, 20(2), https://doi.org/10.5751/ES-07074-200209

Hoerterer, C., Schupp, M. F., Benkens, A., Nickiewicz, D., Krause, G., \& Buck, B. H. (2020). Stakeholder perspectives on opportunities and challenges in achieving sustainable growth of the blue economy in a changing climate. Frontiers in Marine Science, 6, 795. https://doi. org/10.3389/fmars.2019.00795

Hung, H.-C., Lu, Y.-T., \& Hung, C.-H. (2018). The determinants of integrating policy-based and community-based adaptation into coastal hazard risk management: A resilience approach. Journal of Risk Research, 22, 1205-1223. https://doi.org/10.1080/13669877.2018.1454496

Islam, M. M., Sallu, S., Hubacek, K., \& Paavola, J. (2014). Limits and barriers to adaptation to climate variability and change in Bangladeshi coastal fishing communities. Marine Policy, 43, 208-216. https://doi. org/10.1016/j.marpol.2013.06.007

Jackson, F. L., Fryer, R. J., Hannah, D. M., Millar, C. P., \& Malcolm, I. A. (2018). A spatio-temporal statistical model of maximum daily river temperatures to inform the management of Scotland's Atlantic salmon rivers under climate change. Science of the Total Environment, 612, 1543-1558. https://doi.org/10.1016/j.scitotenv.2017.09.010

Joarder, M. A. M., \& Miller, P. W. (2013). Factors affecting whether environmental migration is temporary or permanent: Evidence from Bangladesh. Global Environmental Change, 23, 1511-1524. https:// doi.org/10.1016/j.gloenvcha.2013.07.026

Johnson, J., De Young, C., Bahri, T., Soto, D., \& Virapat, C. (2019). Proceedings of FishAdapt: The Global Conference on Climate Change Adaptation for Fisheries and Aquaculture.

Kaján, E. (2014). Community perceptions to place attachment and tourism development in Finnish Lapland. Tourism Geographies, 16(3), 490511. https://doi.org/10.1080/14616688.2014.941916

Kalikoski, D. C., Jentoft, S., Charles, A., Salazar, D., Herrera, K. C., Béné, C., \& Allison, E. H. (2018). Understanding the impacts of climate change for fisheries and aquaculture: Applying a poverty lens. In M. Barange (Ed.), Impacts of climate change on fisheries and aquaculture: Synthesis of current knowledge, adaptation and mitigation options ( $\mathrm{p}$. 19). FAO Fisheries and Aquaculture Technical Paper No. 627: pp. 19-40.

Kalikoski, D. C., Neto, P. Q., \& Almudi, T. (2010). Building adaptive capacity to climate variability: The case of artisanal fisheries in the estuary of the Patos Lagoon, Brazil. Marine Policy, 34, 742-751. https://doi. org/10.1016/j.marpol.2010.02.003

Khan, A., Charles, A., \& Armitage, D. (2018). Place-based or sectorbased adaptation? A case study of municipal and fishery policy integration. Climate Policy, 18, 14-23. https://doi.org/10.1080/14693 062.2016.1228520
Klain, S. C., Beveridge, R., \& Bennett, N. J. (2014). Ecologically sustainable but unjust? Negotiating equity and authority in common-pool marine resource management. Ecology and Society, 19, 52. https://doi. org/10.5751/ES-07123-190452

Koontz, T. M., Gupta, D., Mudliar, P., \& Ranjan, P. (2015). Adaptive institutions in social-ecological systems governance: A synthesis framework. Environmental Science \& Policy, 53, 139-151. https://doi. org/10.1016/j.envsci.2015.01.003

Krippendorff, K. (2018). Content analysis: An introduction to its methodology (Vol. 4). Sage Publications, pp. 453.

Lesnikowski, A., Ford, J., Biesbroek, R., Berrang-Ford, L., \& Heymann, S. J. (2016). National-level progress on adaptation. Nature Climate Change, 6, 261. https://doi.org/10.1038/nclimate2863

Lim-Camacho, L., Plagányi, E. E., Crimp, S., Hodgkinson, J. H., Hobday, A. J., Howden, S. M., \& Loechel, B. (2017). Complex resource supply chains display higher resilience to simulated climate shocks. Global Environmental Change, 46, 126-138. https://doi.org/10.1016/j.gloen vcha.2017.08.011

Limuwa, M. M., Sitaula, B. K., Njaya, F., \& Storebakken, T. (2018). Evaluation of small-scale fishers' perceptions on climate change and their coping strategies: Insights from Lake Malawi. Climate, 6, 34. https://doi.org/10.3390/cli6020034

Loring, P. A., Fazzino, D. V., Agapito, M., Chuenpagdee, R., Gannon, G., $\&$ Isaacs, M. (2019). Fish and food security in small-scale fisheries. In R. Chuenpagdee, \& S. Jentoft (Eds.), Transdisciplinarity for Small-Scale Fisheries Governance (pp. 55-73). Springer Nature.

Magee, M. R., Hein, C. L., Walsh, J. R., Shannon, P. D., Vander Zanden, M. J., Campbell, T. B., Hansen, G. J. A., Hauxwell, J., LaLiberte, G. D., Parks, T. P., Sass, G. G., Swanston, C. W., \& Janowiak, M. K. (2019). Scientific advances and adaptation strategies for Wisconsin lakes facing climate change. Lake and Reservoir Management, 35, 364-381. https://doi.org/10.1080/10402381.2019.1622612

Makame, M. O., \& Shackleton, S. (2020). Perceptions of climate variability and change in relation to observed data among two east coast communities in Zanzibar, East Africa. Climate and Development, 12, 801-813. https://doi.org/10.1080/17565529.2019.1697633

Malakar, K., Mishra, T., \& Patwardhan, A. (2018). Drivers of response to extreme weather warnings among marine fishermen. Climatic Change, 150, 417-431. https://doi.org/10.1007/s1058 4-018-2284-1

Mantyka-Pringle, C. S., Jardine, T. D., Bradford, L., Bharadwaj, L., Kythreotis, A. P., Fresque-Baxter, J., Kelly, E., Somers, G., Doig, L. E., Jones, P. D., \& Lindenschmidt, K.-E. (2017). Bridging science and traditional knowledge to assess cumulative impacts of stressors on ecosystem health. Environment International, 102, 125-137. https:// doi.org/10.1016/j.envint.2017.02.008

Marschke, M. J., \& Berkes, F. (2006). Exploring strategies that build livelihood resilience: A case from Cambodia. Ecology and Society, 11, 1-16. https://doi.org/10.5751/ES-01730-110142

Marschke, M., Lykhim, O., \& Kim, N. (2014). Can local institutions help sustain livelihoods in an era of fish declines and persistent environmental change? A Cambodian case study. Sustainability, 6, 24902505. https://doi.org/10.3390/su6052490

Marshall, N., Bohensky, E., Curnock, M., Goldberg, J., Gooch, M., Nicotra, B., Pert, P., Scherl, L., Stone-Jovicich, S., \& Tobin, R. (2016). Advances in monitoring the human dimension of natural resource systems: An example from the Great Barrier Reef. Environmental Research Letters, 11, https://doi.org/10.1088/1748-9326/11/11/114020/meta. 114020

McGreavy, B., Randall, S., Quiring, T., Hathaway, C., \& Hillyer, G. (2018). Enhancing adaptive capacities in coastal communities through engaged communication research: Insights from a statewide study of shellfish co-management. Ocean \& Coastal Management, 163, 240253. https://doi.org/10.1016/j.ocecoaman.2018.06.016

Merrifield, M., Gleason, M., Bellquist, L., Kauer, K., Oberhoff, D., Burt, C., Reinecke, S., \& Bell, M. (2019). eCatch: Enabling collaborative 
fisheries management with technology. Ecological Informatics, 52, 82-93. https://doi.org/10.1016/j.ecoinf.2019.05.010

Miller, D. D., Ota, Y., Sumaila, U. R., Cisneros-Montemayor, A. M., \& Cheung, W. W. (2018). Adaptation strategies to climate change in marine systems. Global Change Biology, 24, e1-e14. https://doi. org/10.1111/gcb.13829

Mohamed-Shaffril, H. A., Hamzah, A., D'Silva, J. L., Abu Samah, B., \& Abu Samah, A. (2017). Individual adaptive capacity of small-scale fishermen living in vulnerable areas towards the climate change in Malaysia. Climate and Development, 9, 313-324. https://doi. org/10.1080/17565529.2016.1145100

Monwar, M. M., Mustafa, M. G., Khan, N. A., Hossain, M. S., Hossain, M. M., Majumder, M. K., Chowdhury, R. M., Islam, M. A., Chowdhury, M., \& Alam, M. S. (2018). Indigenous adaptation practices for the development of climate resilient ecosystems in the Hail Haor, Bangladesh. Global Social Welfare, 5, 125-136. https://doi.org/10.1007/s40609-014-0014-9

Muchuru, S., \& Nhamo, G. (2018). Climate change adaptation and the African fisheries: Evidence from the UNFCCC National Communications. Environment, Development and Sustainability, 20, 1687-1705. https://doi.org/10.1007/s10668-017-9960-6

Mulyasari, G., Irham, L. R., Waluyati, L. R., \& Suryantini, A. (2018). Perceptions and local adaptation strategies to climate change of marine capture fishermen in Bengkulu Province, Indonesia. International Conference on Climate Change, 200(1), 012037. https://doi.org/10.10 88/1755-1315/200/1/012037

Musinguzi, L., Efitre, J., Odongkara, K., Ogutu-Ohwayo, R., Muyodi, F., Natugonza, V., Olokotum, M., Namboowa, S., \& Naigaga, S. (2016). Fishers' perceptions of climate change, impacts on their livelihoods and adaptation strategies in environmental change hotspots: A case of Lake Wamala, Uganda. Environment, Development and Sustainability, 18, 1255-1273. https://doi.org/10.1007/s10668-015-9690-6

Norman-López, A., Pascoe, S., Thébaud, O., Van Putten, I., Innes, J., Jennings, S., Hobday, A., Green, B., \& Plaganyi, E. (2014). Price integration in the Australian rock lobster industry: Implications for management and climate change adaptation. Australian Journal of Agricultural and Resource Economics, 58, 43-59. https://doi. org/10.1111/1467-8489.12020

Paukert, C. P., Glazer, B. A., Hansen, G. J., Irwin, B. J., Jacobson, P. C., Kershner, J. L., Shuter, B. J., Whitney, J. E., \& Lynch, A. J. (2016). Adapting inland fisheries management to a changing climate. Fisheries, 41, 374-384. https://doi.org/10.1080/03632415.2016.1185009

Pearce, T., Ford, J. D., Caron, A., \& Kudlak, B. P. (2012). Climate change adaptation planning in remote, resource-dependent communities: An Arctic example. Regional Environmental Change, 12, 825-837. https://doi.org/10.1007/s10113-012-0297-2

Petticrew, M., \& McCartney, G. (2011). Using systematic reviews to separate scientific from policy debate relevant to climate change. American Journal of Preventive Medicine, 40, 576-578. https://doi. org/10.1016/j.amepre.2010.12.022

Piggott-McKellar, A. E., McNamara, K. E., Nunn, P. D., \& Watson, J. E. (2019). What are the barriers to successful community-based climate change adaptation? A review of grey literature. Local Environment, 24 374-390. https://doi.org/10.1080/13549839.2019.1580688

Rahman, S., Islam, M. S., Khan, M. N. H., \& Touhiduzzaman, M. (2019). Climate change adaptation and disaster risk reduction (DRR) through coastal afforestation in South-Central Coast of Bangladesh. Management of Environmental Quality: An International Journal, 30, 498-517. https://doi.org/10.1108/MEQ-01-2018-0021

Sarkar, U. K., Roy, K., Karnatak, G., \& Nandy, S. K. (2018). Adaptive climate change resilient indigenous fisheries strategies in the floodplain wetlands of West Bengal, India. Journal of Water and Climate Change, 9, 449-462. https://doi.org/10.2166/wcc.2018.271

Schemmel, E., Friedlander, A. M., Andrade, P., Keakealani, K., Castro, L. M., Wiggins, C., Wilcox, B. A., Yasutake, Y., \& Kittinger, J. N. (2016). The codevelopment of coastal fisheries monitoring methods to support local management. Ecology and Society, 21, 34. https://doi. org/10.5751/ES-08818-210434

Seara, T., Clay, P. M., \& Colburn, L. L. (2016). Perceived adaptive capacity and natural disasters: A fisheries case study. Global Environmental Change, 38, 49-57. https://doi.org/10.1016/j.gloenvcha.2016.01.006

Seggel, A., \& De Young, C. (2016). Climate change implications for fisheries and aquaculture: Summery of the findings of the Intergovernmental Panel on Climate Change fifth assessment report (pp. 54). Food and Agriculture Organization of the United Nations. In FAO Fisheries and aquaculture technical paper.

Seithi, S., Sundaray, J., Panigrahi, A., \& Chand, S. (2011). Prediction and management of natural disasters through indigenous technical knowledge, with special reference to fisheries. Indian Journal of Traditional Knowledge, 10, 167-172.

Selig, E. R., Kleisner, K. M., Ahoobim, O., Arocha, F., Cruz-Trinidad, A., Fujita, R., Hara, M., Katz, L., McConney, P., Ratner, B. D., SaavedraDíaz, L. M., Schwarz, A.-M., Thiao, D., Torell, E., Troëng, S., \& Villasante, S. (2017). A typology of fisheries management tools: Using experience to catalyse greater success. Fish and Fisheries, 18, 543-570. https://doi.org/10.1111/faf.12192

Sultana, P., \& Thompson, P. (2010). Local institutions for floodplain management in Bangladesh and the influence of the Flood Action Plan. Environmental Hazards, 9, 26-42. https://doi.org/10.3763/ehaz.2010.SI05

Sumaila, U. R., \& Tai, T. C. (2020). End overfishing and increase the resilience of the ocean to climate change. Frontiers in Marine Science, 7 , 523. https://doi.org/10.3389/fmars.2020.00523

Thiault, L., Gelcich, S., Marshall, N., Marshall, P., Chlous, F., \& Claudet, J. (2020). Operationalizing vulnerability for social-ecological integration in conservation and natural resource management. Conservation Letters, 13, e12677. https://doi.org/10.1111/conl.12677

Thomas, A. S., Mangubhai, S., Vandervord, C., Fox, M., \& Nand, Y. (2019). Impact of Tropical Cyclone Winston on women mud crab fishers in Fiji. Climate and Development, 11, 699-709. https://doi. org/10.1080/17565529.2018.1547677

Utete, B., Phiri, C., Mlambo, S. S., Muboko, N., \& Fregene, B. T. (2019). Vulnerability of fisherfolks and their perceptions towards climate change and its impacts on their livelihoods in a peri-urban lake system in Zimbabwe. Environment, Development and Sustainability, 21, 917-934. https://doi.org/10.1007/s10668-017-0067-x

Vaismoradi, M., Jones, J., Turunen, H., \& Snelgrove, S. (2016). Theme development in qualitative content analysis and thematic analysis. Journal of Nursing Education and Practice, 6, 100-110. https://doi. org/10.5430/jnep.v6n5p100

van Putten, I. E., Farmery, A. K., Green, B. S., Hobday, A. J., Lim-Camacho, L., Norman-López, A., \& Parker, R. W. (2016). The environmental impact of two Australian rock lobster fishery supply chains under a changing climate. Journal of Industrial Ecology, 20, 1384-1398. https://doi.org/10.1111/jiec.12382

van Putten, I. E., Jennings, S., Frusher, S., Gardner, C., Haward, M., Hobday, A. J., Nursey-Bray, M., Pecl, G., Punt, A., \& Revill, H. (2013). Building blocks of economic resilience to climate change: $A$ south east Australian fisheries example. Regional Environmental Change, 13, 1313-1323. https://doi.org/10.1007/s10113-013-0456-0

Vogt, N., Pinedo-Vasquez, M., Brondízio, E. S., Rabelo, F. G., Fernandes, K., Almeida, O., Riveiro, S., Deadman, P. J., \& Dou, Y. (2016). Local ecological knowledge and incremental adaptation to changing flood patterns in the Amazon delta. Sustainability Science, 11, 611-623. https://doi.org/10.1007/s11625-015-0352-2

Weeks, R., \& Jupiter, S. D. (2013). Adaptive comanagement of a marine protected area network in Fiji. Conservation Biology, 27, 1234-1244. https://doi.org/10.1111/cobi.12153

Weir, T., Dovey, L., \& Orcherton, D. (2017). Social and cultural issues raised by climate change in Pacific Island countries: An overview. Regional Environmental Change, 17, 1017-1028. https://doi. org/10.1007/s10113-016-1012-5 
Whitney, C. K., \& Ban, N. C. (2019). Barriers and opportunities for social-ecological adaptation to climate change in coastal British Columbia. Ocean \& Coastal Management, 179, 104808. https://doi. org/10.1016/j.ocecoaman.2019.05.010

Wolf, J. (2011). Climate change adaptation as a social process. In D. J. Ford, \& L. Berrang-Ford (Eds.), Climate change adaptation in developed nations: From theory to practice, advances in global change research, Vol. 42 (pp. 21-32). Springer.

Yanda, P. Z., Mabhuye, E., Johnson, N., \& Mwajombe, A. (2019). Nexus between coastal resources and community livelihoods in a changing climate. Journal of Coastal Conservation, 23, 173-183. https://doi. org/10.1007/s11852-018-0650-9

Zhang, J., Fleming, J., \& Goericke, R. (2012). Fishermen's perspectives on climate variability. Marine Policy, 36, 466-472. https://doi. org/10.1016/j.marpol.2011.06.001

\section{SUPPORTING INFORMATION}

Additional supporting information may be found online in the Supporting Information section.

How to cite this article: Galappaththi, E. K., Susarla, V. B., Loutet, S. J. T., Ichien, S. T., Hyman, A. A., \& Ford, J. D. (2021). Climate change adaptation in fisheries. Fish and Fisheries, 00,

1-18. https://doi.org/10.1111/faf.12595 